УДК 616.314.17-008.1-097-06:616.379-008.64

DOI 10.11603/2311-9624.2018.3.9337

(С). Ю. Баліцька, Ю. І. Бондаренко, Г. Г. Габор

ДВН3 «Тернопільський державний медичний університет імені І. Я. Горбачевського» (kindratska@tdmu.edu.ua)

\title{
Роль клітинної ланки адаптивного імунітету в розвитку хронічного генералізованого пародонтиту у хворих із поєднаним перебігом цукрового діабету 2 типу
}

Резюме. У механізмах розвитку запальних процесів ротової порожнини важливу роль відіграють імунні реакції місцевого та системного характеру, особливо на тлі інших поєднаних патологій.

Мета дослідження - з'ясувати характер змін та дати оцінку показникам клітинної ланки адаптивного імунітету при хронічному генералізованому пародонтиті, цукровому діабеті 2 типу та при їх поєднанні.

Матеріали і методи. Проведено обстеження 20 практично здорових осіб (контрольна група), 36 хворих із клінічно встановленим діагнозом цукрового діабету 2 типу (Цд), 32 пацієнтів із підтвердженим діагнозом хронічного генералізованого пародонтиту (ХГП) і 32 хворих із поєднаним Цд і ХГП (четверта група). Дослідження клітинного імунітету проводили на проточному цитофлюориметрі Epics-XL виробництва «Beckman Coulter» (США).

Результати досліджень та їх обговорення. У пацієнтів із цд 2 типу, ХГП та їх поєднанням достовірно зменшувався рівень $\mathrm{CD}^{+}$і $\mathrm{CD} 4^{+}$- Т-лімфоцитів відносно контролю. Найнижчі рівні $\mathrm{CD}^{+}$i $_{\mathrm{CD}} 4^{+}-$ Т-лімфоцитів виявлялися у пацієнтів із ХГП на тлі цд 2 типу. При цьому вміст їх у крові зменшувався відповідно у 2,3 і в 1,4 раза (p<0,001). Розвиток клітинноопосередкованої імуносупресії в пацієнтів із ХГП у поєднанні з цд 2 типу підтверджується також зниженням імунорегуляторного індексу $\left(\mathrm{CD}^{+} /\right.$ $\mathrm{CD}^{+}$) у крові хворих на Цд 2 типу (на 15,0 \%) і у хворих із поєднанням діабету і пародонтиту (на 13,4 \%) ( $<0,05)$. Зменшення активності природних кілерів свідчить про зниження захисних функцій системи клітинного імунітету у хворих на ХГП на тлі Цд 2 типу.

Висновки. Розвиток хронічного генералізованого пародонтиту на тлі цукрового діабету 2 типу супроводжується дисбалансом субпопуляцій Т- і В-лімфоцитів зі зниженням вмісту основних популяцій лімфоцитів із фенотипом CD3+, CD4+, $\mathrm{CD}^{+}$і підвищенням з фенотипом CD22+.

Ключові слова: цукровий діабет 2 типу; хронічний пародонтит; клітинний імунітет.

\author{
(С). Ю. Балицкая, Ю. И. Бондаренко, Г. Г. Габор
}

ГВУЗ «Тернопольский государственный медицинский университет имени И. Я. Горбачевского»

\section{Роль клеточного звена адаптивного иммунитета в развитии хронического генерализованого пародонтита у больных с сочетанным течением сахарного диабета 2 типа}

Резюме. В механизмах развития воспалительных процессов ротовой полости важную роль играют иммунные реакции местного и системного характера, особенно на фоне других объединенных патологий.

Цель исследования - выяснить характер изменений и дать оценку показателям клеточного звена адаптивного иммунитета при хроническом генерализованном пародонтите, сахарном диабете 2 типа и при их сочетании.

Материалы и методы. Проведено обследование 20 практически здоровых лиц (контрольная группа), 36 больных с клинически установленным диагнозом сахарного диабета 2 типа (Сд), 32 пациентов с подтвержденным диагнозом хронического генерализованного пародонтита (ХГП) и 32 больных с совмещенным СД и ХГП (четвертая группа). Исследование клеточного иммунитета проводили на проточном цитофлюориметре Epics-XL производства «Beckman Coulter» (США).

Результаты исследований и их обсуждение. У пациентов с СД 2 типа, ХГП и их сочетанием достоверно уменьшался уровень $\mathrm{CD}^{+}$и $\mathrm{CD}^{+}-\mathrm{T}$-лимфоцитов по отношению к контролю. Наиболее низкие уровни $\mathrm{CD}^{+}$и $\mathrm{CD}^{+}-$T-лимфоцитов оказывались у пациентов с ХГП на фоне Сд 2 типа. При этом со- 
держание их в крови уменьшалось соответственно в 2,3 и в 1,4 раза ( $<<0,001)$. Развитие клеточноопосредованной иммуносупрессии у пациентов с ХГП в сочетании с СД 2 типа подтверждается снижением иммунорегуляторного индекса $\left(\mathrm{CD}^{+} / \mathrm{CD}^{+}\right)$в крови больных СД 2 типа (на 15,0 \%) и у больных с сочетанием диабета и пародонтита (на 13,4 \%) (p<0,05). Снижение активности естественных киллеров свидетельствует о снижении защитных функций системы клеточного иммунитета у больных ХГП на фоне Сд 2 типа.

Выводы. Развитие хронического генерализованного пародонтита на фоне сахарного диабета 2 типа сопровождается дисбалансом субпопуляций Т- и В- лимфоцитов со снижением содержания основных популяций лимфоцитов с фенотипом CD3 ${ }^{+}, \mathrm{CD}^{+}, \mathrm{CD}^{+}$и повышением с фенотипом CD22.

Ключевые слова: сахарный диабет 2 типа; хронический пародонтит; клеточный иммунитет.

\section{(c). Yu. Balitska, Yu. I. Bondarenko, H. H. Gabor}

I. Horbachevsky Ternopil State Medical University

\section{The role of the cellular link of adaptive immunity in the development of chronic generalized periodontitis in patients with a combined course of type 2 diabetes mellitus}

Summary. In the mechanisms of the inflammatory processes development of the oral cavity, an important role is played by the immune responses of the local and systemic nature, especially against the background of other combined pathologies.

The aim of the study - to find out the nature of the changes and to evaluate the parameters of the cellular level of adaptive immunity in chronic generalized periodontitis, type 2 diabetes and their combination.

Materials and Methods. A survey was conducted on 20 practically healthy persons (control group), 36 patients with clinically diagnosed type 2 diabetes mellitus (DM), 32 patients with a confirmed diagnosis of chronic generalized periodontitis (CGP) and 32 patients with combined DM and CGP (group 4). Cell immunity studies were performed on the Epic-XL flow cytometer manufactured by Beckman Coulter (USA).

Results and Discussion. Patients with type 2 diabetes mellitus, CGP and their combination significantly decreased the level of $\mathrm{CD}^{+}$and $\mathrm{CD}^{+} \mathrm{T}$ lymphocytes in relation to control. The lowest levels of $\mathrm{CD}^{+}$and $\mathrm{CD}^{+} \mathrm{T}$ lymphocytes were observed in patients with CGP on the background of DM type 2 . In this case, their content in the blood decreased, respectively, in 2.3 and 1.4 times $(\mathrm{p}<0.001)$. The development of cell-mediated immunosuppression in patients with CGP in combination with type 2 diabetes is also confirmed by a decrease in the immunoregulatory index $\left(\mathrm{CD}^{+} / \mathrm{CD}^{+}\right)$in the blood of patients with type 2 diabetes $(15.0 \%)$ and in patients with a combination of diabetes and periodontitis $(13.4 \%),(p<0.05)$. The decrease in the activity of natural killers indicates a decrease in the protective functions of the system of cellular immunity in patients with CGP on the background of DM 2 type.

Conclusions. Development of chronic generalized periodontitis on the background of type 2 diabetes is accompanied by an imbalance of subpopulations of $\mathrm{T}$ and $\mathrm{B}$ lymphocytes with a decrease in the content of the major populations of lymphocytes with the phenotype - $\mathrm{CD}^{+}, \mathrm{CD}^{+}, \mathrm{CD}^{+}$and increased with the phenotype $\mathrm{CD} 22^{+}$.

Key words: type 2 diabetes mellitus; chronic periodontitis; cell immunity.

Вступ. У механізмах розвитку запальних процесів ротової порожнини значну роль відіграють імунні реакції місцевого та системного характеру, особливо на тлі інших поєднаних патологій. Існують різні наукові точки зору щодо ролі імунопатологічних реакцій у розвитку цукрового діабету (Цд) 2 типу [1]. Зокрема, доведено, що у хворих на цд 2 типу виникає зниження реактивності імунної системи, внаслідок чого спостерігається і тяжчий перебіг інфекційних захворювань [2]. При цьому практично у всіх хворих на Цд виявляється стоматологічна патологія [3]. 3 іншого боку, ряд результатів наукових досліджень свідчить про те, що хронічний пародонтит $€$ імуноопосередкованим захворюванням, що виникає унаслідок комбінованого впливу мікроорганізмів при недостатності захисних процесів тканин пародонта [4].

Метою дослідження було з'ясувати характер змін та дати оцінку показникам клітинної ланки адаптивного імунітету при хронічному 
генералізованому пародонтиті, цукровому діабеті 2 типу та при їх поєднанні.

Матеріали і методи. Проведено обстеження 68 хворих із клінічно встановленим діагнозом цукрового діабету 2 типу (ЦД), які перебували на стаціонарному лікуванні в ендокринологічних й терапевтичних відділеннях лікарень м. Тернополя, а також 32 пацієнтів із підтвердженим хронічним генералізованим пародонтитом (ХГП) у поєднанні з ЦД 2 типу. Встановлення діагнозу захворювань тканин пародонта проводили на основі даних анамнезу, клінічного обстеження, за допомогою визначення гігієнічних і пародонтальних індексів, рентгенологічного дослідження, відповідно до класифікації захворювань пародонта М. Ф. Данилевського (2000) [5]. Осіб, які були включені в дослідження, поділили на 4 групи: перша контрольна - 20 осіб із клінічно здоровим пародонтом, без вираженої загальносоматичної патології; друга - 36 пацієнтів із цд 2 типу; третя - 32 хворих на ХГП і четверта група - 32 пацієнти із ХГП у поєднанні з ЦД 2 типу.

Дослідження клітинного адаптивного імунітету проводили на базі міжкафедральної науково-дослідної лабораторії ДВНЗ «Тернопільський державний медичний університет імені I. Я. Горбачевського МО3 України» на проточному цитофлюориметрі Epics-XL виробництва «Beckman Coulter»

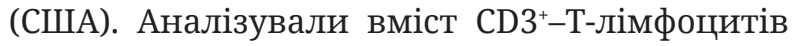

загальних, CD4+-T-лімфоцитів-хелперів, $\mathrm{CD} 8^{+}-$ T-лімфоцитів-супресорів, CD16 $6^{+}$природних кілерів, CD22+- B-лімфоцитів загальних та імунорегуляторний індекс $\mathrm{CD} 4^{+} / \mathrm{CD}^{+}$. Метод дослідження клітинного імунітету грунтується на взаємодії моноклональних антитіл, мічених флюоресцентною міткою, з поверхневими антигенами лімфоцитів [6].

Дані проведених обстежень опрацьовували статистично, використовуючи програму Statistica 8 (StatSoft, США). Для перевірки на відповідність вибірок даних нормальному закону розподілу було застосовано розрахунок критерію Шапіро-Уїлка. У зв’язку з відсутністю відповідності даних нормальному розподілу на рівні значимості $\mathrm{p}<0,05$, обчислювали середньовибіркові характеристики: медіану (Me), першу і третю квартилі (Q25-Q75). Piвень статистичної значущості відмінностей вибірок оцінювали за допомогою непараметричного критерію Манна-Уїтні. Відмінності вважали статистично значущими при досягнутому рівні $\mathrm{p}<0,05$.

Результати досліджень та їх обговорення. Згідно з результатами обстежень, які подані в

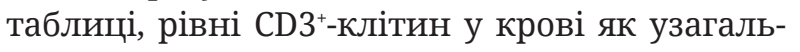
нювального показника Т-клітинної ланки адаптивного імунітету і $\mathrm{CD} 4^{+}$як головного регулятора імунної відповіді були вірогідно нижчими у всіх дослідних групах відносно до аналогічних показників контрольної групи.

таблищя. Вміст Т-лімфоцитів (CD3+, CD4+, CD8+, CD16+, CD22+) у крові хворих на хронічний генералізований пародонтит, цукровий діабет 2 типу, Ме [Q25-Q75] та при поєднаній патології

\begin{tabular}{|c|c|c|c|c|}
\hline \multirow{2}{*}{$\begin{array}{c}\text { Субпопуляція } \\
\text { лімфоцитів }\end{array}$} & \multicolumn{4}{|c|}{ Група обстеження } \\
\cline { 2 - 5 } & $\begin{array}{c}\text { перша група } \\
\text { (контрольна) }(\mathrm{n}=20)\end{array}$ & $\begin{array}{c}\text { друга група (Цд } \\
2 \text { типу) }(\mathrm{n}=36)\end{array}$ & $\begin{array}{c}\text { третя група (ХГП) } \\
(\mathrm{n}=32)\end{array}$ & $\begin{array}{c}\text { четверта група } \\
\text { (ЦД+ХГП) }(\mathrm{n}=32)\end{array}$ \\
\hline $\mathrm{CD}^{+}(\%)$ & $71,19[68,00 ; 77,00]$ & $33,31^{*}[30,75 ; 36,00]$ & $66,38^{*}[59,00 ; 72,00]$ & $31,13^{* \wedge}[29,00 ; 33,25]$ \\
\hline $\mathrm{CD} 4^{+}(\%)$ & $41,10[37,50 ; 45,00]$ & $30,33^{*}[29,00 ; 31,00]$ & $36,41^{*}[33,00 ; 40,00]$ & $28,78^{*} \#[26,75 ; 31,00]$ \\
\hline $\mathrm{CD} 8^{+}(\%)$ & $24,10[20,75 ; 27,25]$ & $20,78^{*}[20,00 ; 22,00]$ & $22,59[20,75 ; 25,00]$ & $19,38^{*} \#[17,00 ; 21,00]$ \\
\hline $\mathrm{CD} 16^{+}(\%)$ & $18,50[16,00 ; 20,00]$ & $22,22^{*}[20,00 ; 24,25]$ & $19,38[17,75 ; 21,00]$ & $24,16^{*} \#[22,00 ; 26,00]$ \\
\hline $\mathrm{CD} 22^{+}(\%)$ & $1,73[1,59 ; 1,90]$ & $1,47^{*}[1,40 ; 1,58]$ & $1,63[1,47 ; 1,82]$ & $1,50 * \#[1,40 ; 1,58]$ \\
\hline
\end{tabular}

Примітки: 1) * - достовірність відмінностей відносно контролю, $\mathbf{p}<0,001 ; \quad$ 2)^ - достовірність відмінностей між другою і четвертою групами, $\mathrm{p}<0,001$; 3) \# - достовірність відмінностей між третьою і четвертою групами, $<<0,001$

У пацієнтів другої дослідної групи показ-

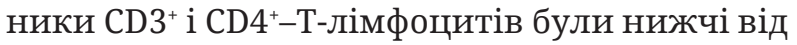
контрольної групи відповідно у 2,2 і в 1,4 раза ( $<00,001)$. У хворих третьої дослідної групи показники CD3+ і CD4+-T-лімфоцитів відповідно також були нижчі від контрольної групи в 1,2 i 1,1 раза $(p<0,05)$. Найнижчі рівні CD3+ i CD4+-T-лімфоцитів виявлено у четвертій дослідній групі. При цьому вміст $\mathrm{CD}^{+}{ }^{+} \mathrm{CD} 4^{+}$ Т-лімфоцитів у крові хворих був менший відповідно у 2,3 і в 1,4 раза порівняно з контрольною групою $(\mathrm{p}<0,001)$. Необхідно зазначити, що виявлені зміни, що спостерігалися в четвертій групі досліджуваних хворих, були 
достовірно нижчими від аналогічних показників хворих на ХГП (CD3+-Т-лімфоцитів - на 49,0 \% і CD4+-T-лімфоцитів - на 18,6 \%), p<0,01 та практично не відрізнялися від хворих другої групи, що $є$ підтвердженням розвитку імунодепресивного стану в пацієнтів із ХГП на тлі Цд 2 типу (рис. 1). Дефіцит Т-хелперної ланки адаптивного клітинного імунітету (зниження CD4+-T-лімфоцитів) у хворих на Цд 2 типу призводить до поглиблення імунних порушень та виникнення умов приєднання ХГП, що, у свою чергу, зумовлює ще більший дисбаланс синтезу відповідних прозапальних і протизапальних цитокінів. Відомо, що у механізмах ініціації хронічного запалення лежить дисбаланс Tx1/Tx2 з порушенням у системі імуно- та цитокіногенезу [7]. Поряд 3 тим спостерігалось вірогідне зниження рівня $\mathrm{CD}^{+}$у другій дослідній групі в 1,2 раза, стосовно контролю $(\mathrm{p}<0,05)$, тоді як у третій групі рівень Т-супресорів статистично значимо не відрізнявся від даних першої групи. Разом 3 тим, у четвертій дослідній групі виявився найнижчий рівень $\mathrm{CD}^{+}$, який порівняно $з$ контрольною групою, був зменшеним в 1,2 раза ( $<<0,001)$. Необхідно зазначити, що виявлені зміни вмісту Т-супресорів у хворих четвертої групи крові були достовірно нижчими від аналогічних показників хворих на ХГП (на 13,4 \%), p<0,05 та практично не відрізнялися від другої групи, що вказує на розвиток більш глибоких змін у Т-клітинній ланці імунної відповіді при поєднанні ХГП і Цд 2 типу.

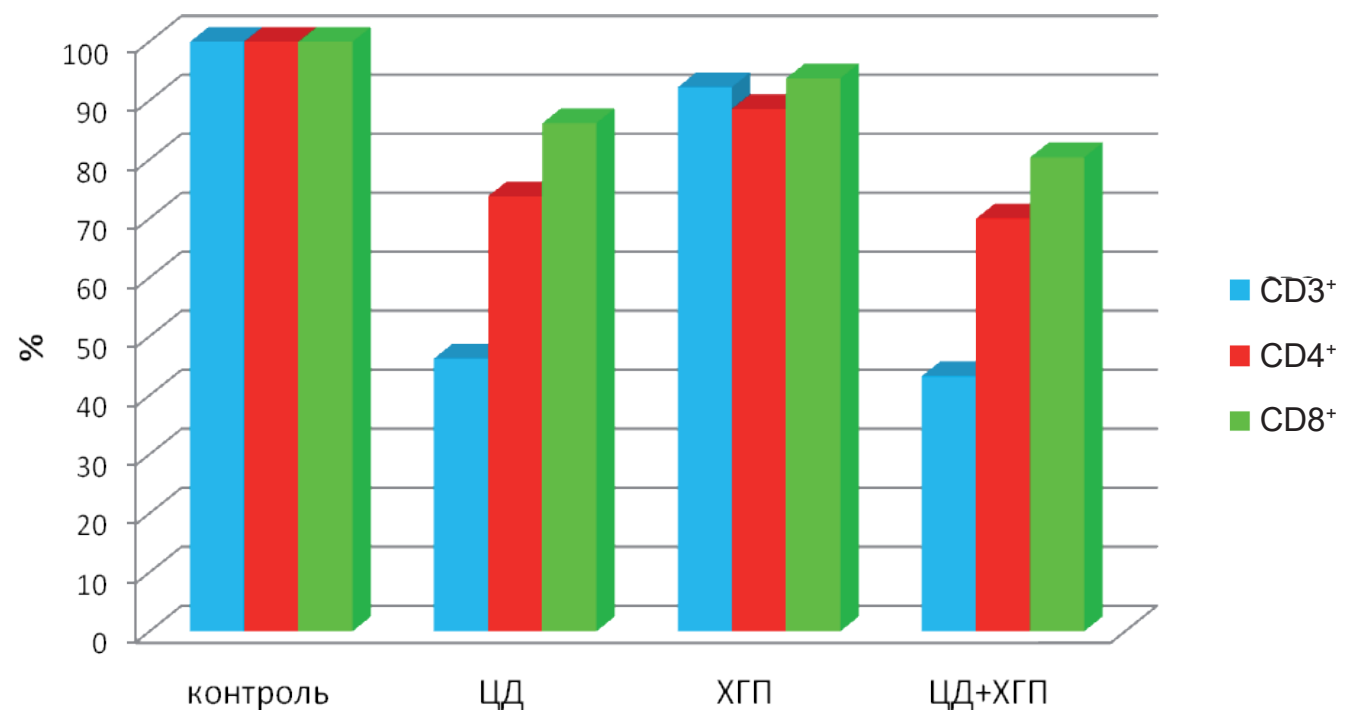

Puc. 1. Динаміка співвідношення субпопуляцій Т-лімфоцитів у крові хворих на хронічний генералізований пародонтит та цукровий діабет 2 типу.

Зміна імунного статусу при ХГП у поєднанні з Цд 2 типу, що проявлялося зниженням основних популяцій (CD3 $\left.{ }^{+}, \mathrm{CD}^{+}, \mathrm{CD} 8^{+}\right)$Т-лімфоцитів периферичної крові, можна пояснити активною міграцією імунних клітин у вогнище ураження, зокрема пародонт, у відповідь на підвищену антигенність тканин пародонтального комплексу.

Розвиток клітинноопосередкованої імуносупресії підтверджується зниженням імунорегуляторного індексу $\left(\mathrm{CD}^{+} / \mathrm{CD}^{+}\right)$у хворих на хронічним генералізований пародонтит в поєднанні з Цд 2 типу (рис. 2). Так, у даних дослідженнях було виявлено зменшення співвідношення $\mathrm{CD}^{+} / \mathrm{CD}^{+}$у крові хворих другої дослідної групи на 15,0 \% і четвертої групи на $13,4 \%$, стосовно контролю $(\mathrm{p}<0,05)$. Разом 3 тим, варто зазначити, що у пацієнтів із ХГП даний показник також мав тенденцію до зниження, проте статистично не відрізнявся від даних першої групи. Отримані дані вказують на розвиток клітинноопосередкованої імуносупресії у хворих на Цд 2 типу та поєднану патологію, зокрема ХГП.

Аналіз змін рівнів CD16 ${ }^{+}$у групах обстеження вказує на зниження досліджуваного показника у другій (на 16,8 \%) і четвертій (на 30,4 \%) групах, p <0,01. Зниження активності природних кілерів свідчить про пригнічення захисних функцій системи адаптивного клітинного імунітету у хворих на хронічний генералізований пародонтит на тлі цукрового діабету 2 типу (рис. 3).

Дослідження рівня CD22+-лімфоцитів у групах обстеження вказує на підвищення досліджуваного показника у другій (на 20,1 \%) i четвертій (на 30,6 \%) групах, p<0,001 (рис. 4). 


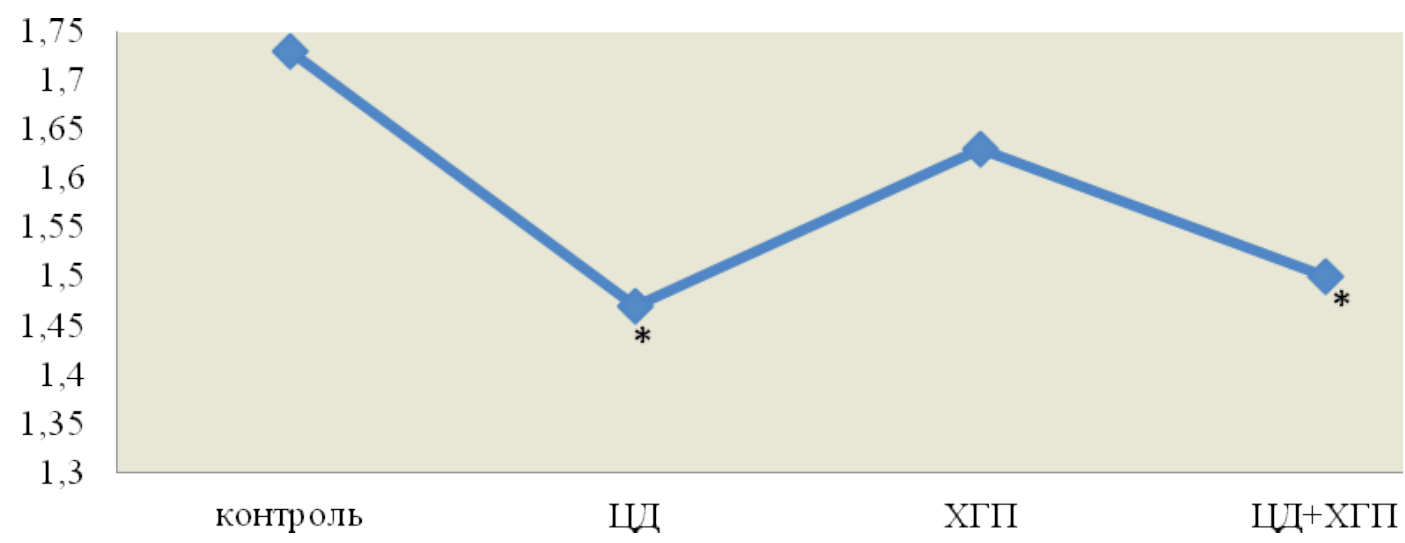

Puc. 2. Динаміка імунорегуляторного індексу $\left(\mathrm{CD} 4^{+} / \mathrm{CD} 8^{+}\right)$у хворих на цукровий діабет 2 типу та патологію тканин пародонта.

Примітка. * - достовірність відмінностей порівняно з контролем.

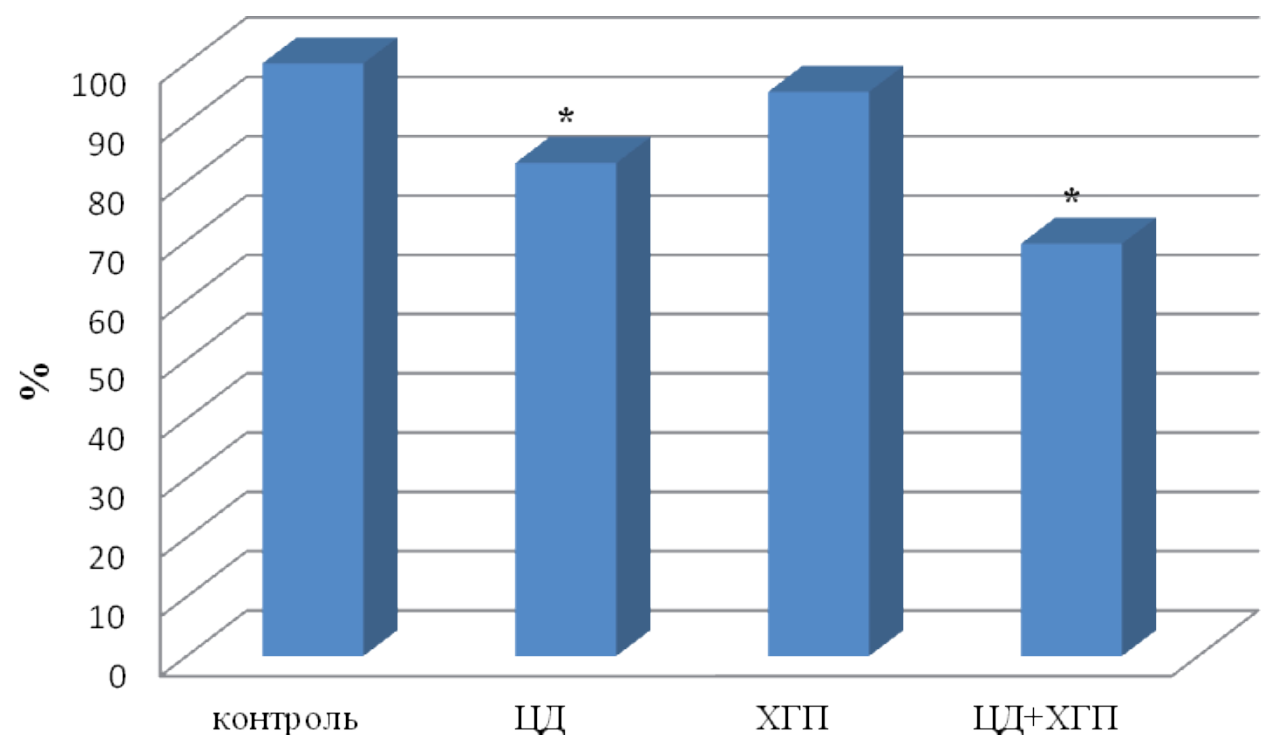

Puc. 3. Динаміка CD16+-T-лімфоцитів у крові хворих на хронічний генералізований пародонтит на тлі цукрового діабету 2 типу.

Примітка. * - достовірність відмінностей порівняно з контролем.

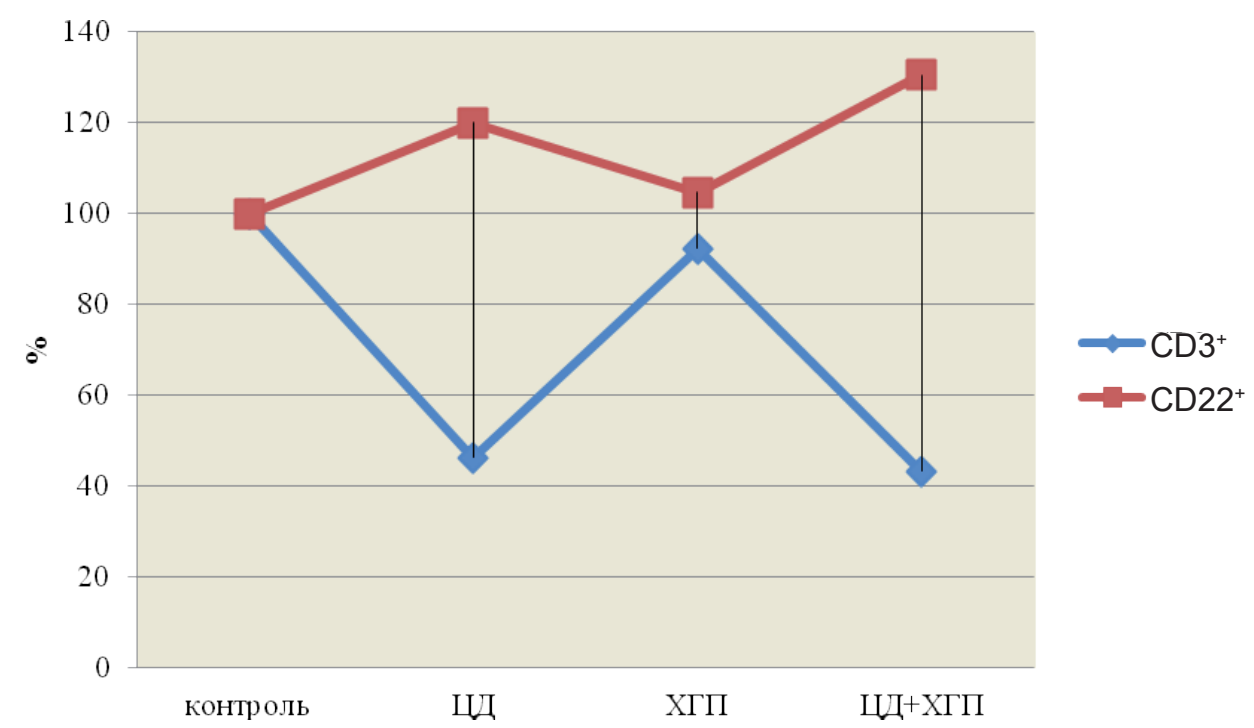

Puc. 4. Динаміка співвідношення $\mathrm{CD} 3^{+}$і CD22+-T-лімфоцитів у крові хворих на хронічний генералізований пародонтит на тлі цукрового діабету 2 типу. 
Таким чином, хронічний генералізований пародонтит на тлі цукрового діабету 2 типу характеризується дисбалансом субпопуляцій Т- і B- лімфоцитів зі зниженням вмісту основних популяцій лімфоцитів із фенотипом $\mathrm{CD}^{+}$, $\mathrm{CD} 4^{+}, \mathrm{CD} 8^{+}$і підвищенням із фенотипом CD22+, який не є винятково місцевою реакцією, а супроводжується різноспрямованими змінами в ланках адаптивного імунітету (рис. 4).

Отже, у хворих на ЦД 2 типу дефіцит Т-хелперної ланки адаптивного клітинного імунітету призводить до поглиблення імунних порушень та зумовлює дисбаланс синтезу відповідних прозапальних і протизапальних цитокінів. Наукові дані свідчать про те, що за умови запального навантаження при хронічних захворюваннях із втягненням у патологічний процес прозапальних цитокінів виявляються й значні пародонтальні порушення [8]. Відомо, що в порожнині рота постійно присутні бактерії, які безпосередньо контактують у складі зубної бляшки 3 тканинами пародонта і здатні виробляти велику кількість біологічно активних речовин: ліполісахаридний токсин, лейкотоксини, колагенази, гідролітичні протеази та інші. Згідно $з$ результатами сучасних наукових досліджень, встановлено, що ушкодження тканин пародонта відбувається не безпосередньо від токсичності бактеріальних факторів, а від здатності бактеріальних компонентів впли-

\section{Список літератури}

1. Мерецька I. В. Вплив нового гіпоглікемічного рослинного збору на стан імунного статусу при цукровому діабеті / I. В. Мерецька // Таврический медико-биологический вестник. - 2012. - Т. 15, № 4 (60). С. 251-253.

2. Summaries for patients. Screening for type 2 diabetes in adults: U.S. Preventive Services Task Force recommendations // Ann. Intern. Med. - 2008. - Vol. 148, No.11. - P. I30-134.

3. Diabetes enhances dental caries and apical periodontitis in caries-susceptible WBN/KobSlc rats / Y. Kodama, M. Matsuura, T. Sano [et al.] // Comp. Med. 2011. - Vol. 6, No. 1. - P. 53-59.

4. Борисенко А. В. Біохімічне обгрунтування комплексного лікування генералізованого пародонтиту науковцями кафедри терапевтичної стоматології Національного медичного університету ім. О. О. Богомольця / А. В. Борисенко // Терапевтическая стоматология. - 2014. - № 2. - С. 12-20.

5. Данилевский Н. Ф. Заболевания пародонта / вати на імунну відповідь [9]. Тому можна допустити, що розвиток пародонтиту в пацієнтів четвертої групи є наслідком дисрегуляції імунної системи при Цд 2типу.

Висновки. 1. У хворих на хронічний генералізований пародонтит, цукровий діабет 2 типу та 3 поєднанням даної патології знижується рівень у крові CD3+-клітин і $\mathrm{CD} 4^{+}$відносно аналогічних показників контрольної гру-

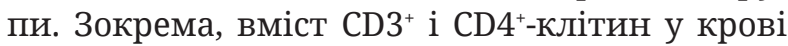
пацієнтів із хронічним пародонтитом на тлі цукрового діабету 2 типу менший відповідно у 2,3 і в 1,4 раза порівняно 3 контрольною групою $(\mathrm{p}<0,001)$.

2. Свідченням розвитку клітинноопосередкованої імуносупресії у хворих на хронічний генералізований пародонтит у поєднанні 3 цд 2 типу є зниженням імунорегуляторного індексу $\left(\mathrm{CD}^{+} / \mathrm{CD}^{+}\right)$, зокрема у хворих на цукровий діабет 2 типу (на 15,0 \%) і у пацієнтів із поєднанням діабету і пародонтиту (на 13,4 \%), стосовно контролю $(\mathrm{p}<0,05)$.

3. Хронічний генералізований пародонтит на тлі цукрового діабету 2 типу супроводжується дисбалансом субпопуляцій Т- і В- лімфоцитів зі зниженням вмісту основних популяцій лімфоцитів із фенотипом $\mathrm{CD} 3^{+}, \mathrm{CD}^{+}, \mathrm{CD} 8^{+}$ i підвищенням з фенотипом CD22, який не $\epsilon$ винятково місцевою реакцією, а супроводжується різноспрямованими змінами в клітинній ланці адаптивного імунітету.

Н. Ф. Данилевский, А. В. Борисенко. - К. : Здоров’я, 2000. -464 c.

6. Bunders M. Age-related standards for total lymphocyte, $\mathrm{CD}^{+}$and $\mathrm{CD}^{+} \mathrm{T}$ cell counts in children born in Europe / M. Bunders, M. Cortina-Borja, M. L Newell // Pediatr. Infect. Dis. J. - 2005. - Vol. 24, No. 7. P. 595-600.

7. Аллергические заболевания у детей: особенности цитокинового и иммунного статуса / Е. В. Просекова, В. В. Деркач, Т. Н. Шестоковская [и др.] // Иммунология. - 2007. - № 3. - С. 157-161.

8. El-Shinnawi U. Associations between periodontitis and systemic inflammatory diseases: response to treatment / U. ElShinnawi, M. Soory // Recent. Pat. Endocr. Metab. Immune Drug. Discov. - 2013. - Vol. 7. No. 3. - P. 169-188.

9. Periodontal disease immunology: «double indemnity» inprotecting the host / J. L. Ebersole, D. R. Dawson 3rd, L. A. Morford [et al.] // Periodontol. - 2000. - 2013. - Vol. 62, No. 1. - P. 163-202. 


\section{References}

1. Meretska,I.V.(2012).Vplyvnovoho hipohlikemichnoho roslynnoho zboru na stan imunnoho statusu pry tsukrovomu diabeti [Influence of new hypoglycemic plant collection on the state of immune status in diabetes mellitus]. Tavricheskiy mediko-biologicheskiy vestnik - Tavricheskiy Medico-biological Bulletin, 15 (4), 251-253 [in Ukrainian].

2. (2008). Summaries for patients. Screening for type 2 diabetes in adults: U.S. Preventive Services Task Force recommendations. Ann. Intern. Med., 148 (11), 130-134. 3. Kodama, Y., Matsuura, M., Sano, T. (2011). Diabetes enhances dental caries and apical periodontitis in caries-susceptible WBN/KobSlc rats. Comp. Med., 6 (1), 53-59.

4. Borysenko, A.V. (2014). Biokhimichne obhruntuvannia kompleksnoho likuvannia heneralizovanoho parodontytu naukovtsiamy kafedry terapevtychnoi stomatolohii Natsionalnoho medychnoho universytetu im. O.O. Bohomoltsia [Biochemical substantiation of complex treatment of generalized periodontitis by scientists of the Department of Therapeutic Dentistry of the National Medical University named after
O.O. Bohomolets]. Terapevticheskaya stomatologiya Therapeutic Stomatology, 2, 12-20 [in Ukrainian].

5. Danilevskiy, N.F., \& Borisenko, A.V. (2000). Zabolevaniya parodonta [Periodontal disease]. Kiev: Zdorovye [in Russian].

6. Bunders, M., Cortina-Borja, M., Newell, M.L. (2005). Age-related standards for total lymphocyte, CD4+ and CD8+ T cell counts in children born in Europe. Pediatr. Infect. Di. J., 24 (7), 595-600.

7. Prosekova, E.V., Derkach, V.V., \& Shestokovskaya, T.N. (2007). Allergicheskiye zabolevaniya u detey: osobennosti tsytokinovogo i immunnogo statusa [Allergic diseases in children: features of cytokine and immune status]. Immunologiya - Immunology, 3, 157161 [in Russian].

8. El-Shinnawi, U., \& Soory, M. (2013). Associations between periodontitis and systemic inflammatory diseases: response to treatment. Recent Pat. Endocr. Metab. Immune Drug Discov., 7 (3), 169-188.

9. Ebersole, J.L., Dawson 3rd, D.R., \& Morford, L.A. (2013). Periodontal disease immunology: "double indemnity» inprotecting the host. Periodontol., 62 (1), 163-202.

Отримано 02.08.18 